Acta vet. scand. $1961,2,129-136$.

From the medical department for non-ruminants, Royal Veterinary College, Stockholm.

\title{
BLOOD-PRESSURE IN DOGS WITH RENAL CORTICAL HYPOPLASIA
}

By

F. Persson, S. Persson and Å. Åsheim

In earlier reports on renal cortical hypoplasia in dogs accounts have been given of the clinical picture of the disease, with special reference to the uraemia and the secondary hyperparathyreoidism and to electrocardiographic changes in the uraemia due to renal cortical hypoplasia. In his works on the pathology of renal cortical hypoplasia in the dog Krook (1957) points out that some of the non-renal changes in this disease are caused by hypertension. It has long been known that some chronic renal disorders in man are attended by a raised blood-pressure. The occurrence of spontaneous renal hypertension in the dog has been much debated. The strongest supporting evidence for the occurrence of renal hypertension is considered to be the hypertrophy of the left side of the heart often seen at autopsy of uraemic cases (Nieberle and Cohrs, 1954). In the study presented here results of blood-pressure determinations in dogs with renal cortical hypoplasia will be reported. Normal values from blood-pressure measurements will also be reported.

\section{MATERIAL AND METHODS}

The studies concerned partly dogs admitted to the medical clinic of the Veterinary College over the years 1955-1960, and partly experimental dogs. All were cocker-spaniels with recognized renal cortical hypoplasia. The first group comprised 7 dogs, 5 males and 2 females. Their ages ranged from 8 to 18 months. Six of the seven dogs were subjected to autopsy, at which the diagnosis was verified. The experimental dogs were obtained from parents that had earlier born puppies with renal cortical hypoplasia. In this group, which consisted of 21 dogs from 5 
litters, the disease manifested itself in 3 dogs, all females. These three died at the age of $10,16 \frac{1}{2}$ and $17 \frac{1}{2}$ months, respectively. All the dogs in the experimental group were subjected to continuous clinical investigations, including blood-pressure measurements. The blood-pressure values for the healthy dogs were treated statistically and regarded as a normal material.

The blood-pressure was measured by a direct method, using a polyethylene catheter inserted into the femoral artery and connected with a mercurial manometer. The mean arterial pressure was thus obtained. In most of the dogs the blood-pressure recordings were done on the same occasion as renal clearance determinations were performed under anaesthesia with "Mebumal". ${ }^{1}$ ) In some cases of the clinical material the blood-pressure was recorded in non-anaesthetized dogs. The dogs did not show any unfavourable responses that might be thought to have influenced blood-pressure.

\section{RESULTS}

From the continuous blood-pressure measurements in the $\mathbf{1 6}$ healthy experimental dogs one value from each dog, taken at the age of approximately 12 months, was selected for statistical analysis. The result of the latter is presented in Table 1, in which the values both for the normal and for the hypoplastic dogs are given.

Table 1 .

Blood-pressure in normal dogs and in dogs with renal cortical hypoplasia. The values are given as $\mathrm{mm} \mathrm{Hg}$.

\begin{tabular}{lccccc}
\hline & $\begin{array}{c}\text { Number of } \\
\text { dogs }\end{array}$ & Range & Mean & $\begin{array}{c}\text { Standard } \\
\text { deviation }\end{array}$ & $\begin{array}{c}\text { Standard } \\
\text { error } \\
\text { of mean }\end{array}$ \\
\hline $\begin{array}{l}\text { Normal dogs } \\
\begin{array}{l}\text { Dogs with renal } \\
\text { cortical hypoplasia }\end{array}\end{array}$ & 16 & $130-160$ & 148 & 8.7 & 2.2 \\
\hline
\end{tabular}

1) The formula of "Mebumal" is as follows:

5-ethyl-5(1-methylbutyl)-malonylcarbamide (pentobarbitone) $1.8 \mathrm{~g}$

Pentobarbitone sodium

$4.0 \mathrm{~g}$

Urethane

$25.0 \mathrm{~g}$

Spir. conc.

$15.0 \mathrm{~g}$

Glycerin

$12.5 \mathrm{~g}$

Aq. steril.

ad $100 \mathrm{ml}$ 
In the comparison of the values given in Table 1 Student's t-test was used for determining the degree of significance. No significant difference in blood-pressure was found between healthy and hypoplastic dogs $(P>0.05)$. Table 2 shows in detail the results of the different blood-pressure recordings as well as the state of the heart at autopsy.

Table 2 .

Blood-picture, mean arterial pressure, and state of heart at autopsy in dogs with renal cortical hypoplasia.

\begin{tabular}{|c|c|c|c|c|c|c|c|}
\hline Dog & $\begin{array}{l}\text { Clinically } \\
\text { observable } \\
\text { anaemia } \\
(+)\end{array}$ & $\begin{array}{l}\text { Red-cell } \\
\text { count } \\
1000000 \\
/ \text { c. } \mathbf{m m}\end{array}$ & $\begin{array}{l}\text { Haemo- } \\
\text { globin } \\
\text { mg/ } \\
100 \mathrm{ml}\end{array}$ & $\begin{array}{c}\text { Date } \\
\text { of } \\
\text { death }\end{array}$ & $\begin{array}{l}\text { Date of } \\
\text { blood- } \\
\text { pressure } \\
\text { measure- } \\
\text { ment. }\end{array}$ & $\begin{array}{l}\text { Mean } \\
\text { arterial } \\
\text { pressure } \\
\text { mm Hg }\end{array}$ & $\begin{array}{l}\text { State of heart at } \\
\text { autopsy }\end{array}$ \\
\hline $888 / 56$ & + & 2.4 & 5.9 & $25 / 10$ & $24 / 10$ & 155 & $\begin{array}{l}\text { Eccentric hypertrophy } \\
\text { Chronic myocarditis }\end{array}$ \\
\hline $1040 / 56 \sigma^{x}$ & + & 5.2 & 12.5 & $5 / 12$ & $5 / 12$ & 145 & Eccentric hypertrophy \\
\hline $1109 / 57$ q & + & 4.2 & 11.0 & $17 / 11$ & $14 / 11$ & 120 & $\begin{array}{l}\text { Eccentric hypertrophy } \\
\text { Acute focal myocarditis }\end{array}$ \\
\hline $313 / 58 \sigma^{x}$ & 一 & 5.2 & 13.9 & $15 / 4$ & $\begin{array}{l}11 / 4 \\
15 / 4\end{array}$ & $\begin{array}{l}165 \\
100\end{array}$ & Autopsy not performed \\
\hline $160 / 60 \sigma^{x}$ & + & 4.0 & 9.2 & $2 / 3$ & $26 / 2$ & 140 & Eccentric hypertrophy \\
\hline E $600^{x}$ & + & & 13.2 & $5 / 3$ & $4 / 3$ & 105 & $\begin{array}{l}\text { Eccentric hypertrophy } \\
\text { Fatty degeneration of } \\
\text { myocardium }\end{array}$ \\
\hline N $49 \sigma^{x}$ & + & 2.8 & 7.1 & $15 / 6$ & $\begin{array}{r}24 / 3 \\
6 / 5 \\
14 / 6\end{array}$ & $\begin{array}{l}130 \\
130 \\
130\end{array}$ & Eccentric hypertrophy \\
\hline I : 1 q & + & 4.6 & 7.4 & $22 / 10$ & $\begin{array}{c}1 / 2 \\
15 / 5 \\
9 / 9 \\
13 / 9 \\
21 / 10\end{array}$ & $\begin{array}{l}150 \\
170 \\
137 \\
140 \\
105\end{array}$ & Eccentric hypertrophy \\
\hline II : 4 우 & - & 7.2 & 16.8 & $29 / 5$ & $27 / 5$ & 125 & $\begin{array}{l}\text { Chronic focal myo- } \\
\text { carditis }\end{array}$ \\
\hline $\mathrm{V}: 7$ ㅇ & - & 5.9 & 15.7 & $19 / 1-59$ & $\begin{array}{ll}12 / 12-57 \\
29 / 1 & -58 \\
11 / 4 & -58 \\
12 / 6 & -58\end{array}$ & $\begin{array}{l}130 \\
155 \\
140 \\
145\end{array}$ & $\begin{array}{l}\text { Dilatation of right } \\
\text { ventricle }\end{array}$ \\
\hline
\end{tabular}




\section{DISCUSSION}

The normal blood-pressure values recorded in Table 1 agree well with values reported earlier (Hamilton et al., 1939; Katz et al., 1939; Wakerlin, 1943; McCubbin and Corcoran, 1953; Romagnoli, 1953; Katz, Skom and Wakerlin, 1957; Schulze, 1958).

Among the non-renal changes which occur in uraemia and which are considered to be due to the renal hypertension, the eccentric cardiac hypertrophy and the arteriosclerotic changes are the most important ones. As early as 1827 Bright reported that he had observed co-existing renal lesions and heart disease in man. Goldblatt's experiment in 1934, in which he was able to produce hypertension in dogs by closure of the renal artery, has become classical. Numerous authors have since then demonstrated the important role of renal lesions in the development of hypertension in man. Floyer (1957), in a recent work, mentions the occurrence of two different phases in renal hypertension: 1) an early phase in which a renal pressor substance is secreted from the kidney, and 2) a late phase in which the high blood-pressure is maintained by an extrarenal mechanism. In a previous work (Helander, Persson and Åsheim, 1958) we showed that a constriction of the renal artery on one side produces a corresponding change in the function of the other kidney. The same phenomenon has been observed by Floyer, who presumes that it is due to secretion of a humoral substance and that this would possibly be identical with the above-mentioned pressor substance.

The question whether raised blood-pressure occurs in dogs is a subject of controversy. Experimental renal hypertension in dogs on the model of Goldblatt's experiment has been induced by many workers (Katz et al., Stamler, Katz and Rodbard, 1949; Stamler, Rodbard and Katz, 1950; Campbell, 1954; Floyer). Others (Morehead and Little, 1945; McIntyre and Montgomery, 1952; Platt, 1952; Baur, 1955; Dahme, 1956; Dahme, 1957; Krook, 1957) have taken the autopsy findings in uraemic cases, notably the eccentric hypertrophy of the heart, as evidence supporting the presence of renal hypertension. It is only in recent years that the intra-arterial blood-pressure in normal dogs has been measured on such a large scale that normal values have been obtained. Occasional cases of spontaneous hypertension in asso- 
ciation with renal disorders have been reported (Wakerlin, McCubbin and Corcoran, Katz, Skom and Wakerlin).

More systematic blood-pressure studies by a direct method in dogs with renal disease have been done by Robin (1948) and Schulze. Robin does not believe that renal hypertension occurs in dogs and considers that the hypertension and the hypertrophy of the left side of the heart have a common renal cause. Schulze reports that out of $56 \mathrm{dogs}$ with renal disease 4 dogs with chronic interstitial nephritis had raised blood-pressure. It should be noted, however, that he has fixed the upper limit for normal pressure at $150 \mathrm{~mm} \mathrm{Hg}$ for the mean arterial pressure. Gärtner (1956), without mentioning the technique used at the bloodpressure measurement, reports hypertension in 5 cases of glomerulonephritis and states that together with haematuria, ascites and oedema, hypertension would be the cardinal symptom in cases of acute glomerulonephritis. Hamilton et al. also observed hypertension in cases of glomerulonephritis.

It will be seen from Tables 1 and 2 that in 10 dogs with renal cortical hypoplasia, in which the blood-pressure was measured, no significantly raised pressure was recorded. Only on one occasion in dog no. I: 1 did the blood-pressure reach the borderline value of $170 \mathrm{~mm} \mathrm{Hg}$. In all the dogs, excepting no:s 160/60, E: 60 and $\mathrm{N} 49$, light anaesthesia was induced with "Mebumal". Hamilton et al. state that surgical anaesthesia with barbiturates has the effect of lowering blood-pressure in the hypertensive dogs. As has also been pointed out in earlier publications (Helander, Persson and Åsheim, Åsheim, Helander and Persson, 1958), we have made repeated experiments with continuous recording of blood-pressure before and during the induction of anaesthesia and during anaesthesia. A slight rise of blood-pressure, about $10-15 \mathrm{~mm} \mathrm{Hg}$, occurred during injection of "Mebumal", but after a minute or two the pressure returned to normal. In one experiment the dog was allowed to wake up during the bloodpressure recording. On awakening he went into a state of excitation, which caused a rise in blood-pressure. After about 25 minutes, when the dog had calmed down, the blood-pressure had fallen to the same level as before and during the anaesthesia. In the three dogs that were not anaesthetized the blood-pressure was consistent with that of the others.

In a not yet published study on blood-pressure measurements in dogs with renal disease the blood-pressure was recorded with- 
out anaesthesia. The values for that material will apparently agree with the values for the hypoplastic dogs.

Since our investigations thus show that raised blood-pressure in the dog is not at all so common as has been asserted in earlier reports, in which the assumption of a raised blood-pressure was mainly based on the autopsy findings, it is of interest to study Table 2. It will be seen from the table that eccentric cardiac hypertrophy or other pathological changes of the heart were present in all the autopsy cases. Accordingly, these observations indicate that eccentric cardiac hypertrophy occurs in the absence of hypertension. Therefore, an essential cause of the hypertrophy must be some factor other than hypertension. From this study, and from what has been shown earlier, it is quite clear that there is a very close relationship between renal disorders and hypertrophy of the heart. It is therefore probable that by some secondary mechanism other than hypertension renal lesions would give rise to cardiac hypertrophy. In man the anaemia (Spühler and Zollinger, 1953) is considered to be a very important symptom and one of the first to appear in renal diseases. Some authors (Hare, 1934; Hogg, 1948; Niemand, 1954; Nielsen and McSherry, 1954; Paplanus, Zbar and Hays, 1958) have also reported the presence of anaemia in dogs. The tendency to anaemia in hypoplastic dogs is evident in Table 2. Elsewhere we have shown that there is a significant difference between healthy and hypoplastic dogs with respect to both the red-cell count and the haemoglobin concentration. Among our 10 cases anaemic mucous membranes were also seen clinically in 7 . More recent studies (Forssell, 1958; Naetz, 1958) have shown that the cause of anaemia in cases of chronic uraemia is the lack of erythropoietin, a substance which is formed in the kidneys and whose function is to stimulate bone-marrow activity. The production of erythropoietin is stimulated by different forms of anoxia. Since it can be considered established that the nephrogenic anaemias are of greater importance than has earlier been appreciated, it may be hypothesized that the eccentric cardiac hypertrophy would arise as a result of the increased stroke volume with which the heart must work in anaemia. Paplanus et al., in experiments on dogs, have demonstrated that anaemia induced by repeated venesection gives rise to hypertrophy and dilatation of the heart. 


\section{REFERENCES}

Baur, L.: Morphologische Betrachtungen über Herzmuskel- und Herzgefässerkrankungen bei der Herzmuskelhypertrophie des Hundes. Zugleich ein Beitrag zum Problem "Hypertonie und Arteriosklerose". Vet. Diss. München 1955.

Campbell, M.: Circulat. Res. 1954, 2, 243.

Dahme, E.: Tierärztl. Wschr. 1956, 63, 49.

Dahme, E.: Arch. exp. Vet.-Med. 1957, 11, 611 \& 752.

Floyer, M. A.: Brit. med. Bull. 1957, 13, 29.

Forssell, J.: Acta med. scand. 1958, 161, 169.

Goldblatt, H., Lynch, J., Hanzal, R. F. and Summerville, W. W.: J. exper. Med. 1934, 59, 347.

Gärtner, K.: Mh. Vet.-Med. 1956, 11, 479.

Hamilton, W. F., Pund, E. R., Slaughter, R. F., Simpson, W. A., Colson, G. M., Coleman, H. W. and Bateman, W. H.: Amer. J. Physiol., 1939, 128, 233.

Hare, T.: Proc. roy. Soc. Med. 1933/34, 29:2, 789.

Helander, C. G., Persson, F. and Åsheim, Å.: Acta physiol. scand. 1958, 44, 1.

Hogg, A. H.: Vet. Rec. 1948, 60, 117.

Katz, L. N., Friedman, M., Rodbard, S. and Weinstein, W.: Amer. Heart J. 1939, 17, 334.

Katz, J. I., Skom, J. H. and Wakerlin, G. E.: Circulat. Rec. 1957, 5, 137.

Krook, L.: Acta path. microbiol. scand., Suppl. 122, 41, 1957.

McCubbin, J. W. and Corcoran, A. C.: Proc. Soc. exper. Biol. Med. $1953,84,130$.

McIntyre, W. I. M. and Montgomery, G. L.: J. Path. Bact. 1952, 64, 145.

Morehead, R. P. and Little, J. M.: Amer. J. Path. 1945, 21, 339.

Naetz, J. P.: Nature, 1958, 182, 1516.

Nieberle und Cohrs: Lehrbuch der Spez. Path. Anat. d. Haust., Jena, 1954, p. 26.

Nielsen, S. W. and McSherry, B. J.: J. Amer. vet. med. Ass. 1954, 124, 270.

Niemand, H. G.: Tierärztl. Umsch. 1954, 9, 89.

Paplanus, S. H., Zbar, M. J. and Hays, J. W.: Amer. J. Path. 1958, 34, 149.

Platt, H.: J. Path. Bact. 1952, 64, 539.

Robin, V.: Rev. Path. comp. 1948, 48, 442.

Romagnoli, A.: Cornell Vet. 1953, 43, 161.

Schulze, G.: Klinische Blutdruckmessungen durch Punktion der arteria femoralis bei nierenkranken Hunden. Vet. Diss. Hannover 1958.

Spühler, O. und Zollinger, H. U.: Z. klin. Med. 1953, 151, 1.

Stamler, J., Katz, L. N. and Rodbard, S.: J. exper. Med. 1949, 90, 511.

Stamler, J., Rodbard, S. and Katz, L. N.: Amer. J. Physiol. 1950, $160,21$.

Wakerlin, G. E.: J. Amer. vet. med. Ass. 1943, $102,346$.

Åsheim, Å., Helander, C. G. and Persson, F.: Acta physiol. scand. 1958, 44, 103. 


\section{SUMMARY}

The blood-pressure in young dogs of the cocker spaniel breed was measured by a direct method. The mean arterial pressure in healthy dogs was $148 \mathrm{~mm} \mathrm{Hg}$ with a standard deviation of 8.7. Among 10 dogs with renal cortical hypoplasia a raised blood-pressure was not recorded in any case. The hypertrophy of the left side of the heart observed at autopsy is hypothetically explained by the anaemia.

\section{ZUSAMMENFASSUNG}

Der Blutdruck bei Hunden mit Nierenrindehypoplasie.

Bei jungen Hunden der Cockerspanielrasse wurden Blutdruckbestimmungen mittels direkter Methode durchgeführt. Der arterielle Druck betrug im Durchschnitt 148 mit einer Standardabweichung von 8,7. Bei zehn Hunden mit Hypoplasie der Nierenrinde, wurde keine Blutdruckerhöhung festgestellt. Die bei der Sektion bemerkte Hypertrophie der linken Herzhälfte wird hypothetischerweise durch das Vorkommen einer Anämie erklärt.

\section{SAMMANFATTNING}

Blodtrycket hos hundar med njurbarkshypoplasi.

Blodtrycksbestämningar hos unga hundar av cockerspaniel-ras har utförts med direkt metod. Medelartärtrycket för friska hundar var 148 med stand. dev. 8,7. Hos 10 hundar med njurbarkshypoplasi kunde förhöjt blodtryck ej registreras i något fall. Den vid sektion iakttagna vänstersidiga hjärthypertrofin förklaras hypotetiskt av den förekommande anämin. 